\title{
Effects of Phytohormone and Regulators on Shoot Tip and Nodal Explants for In Vitro Shoot and Root Clonal Propagation of Vitex negundo $\mathrm{L}$
}

\author{
Safia Iqbal ${ }^{1,3}$, A.K.M. Nazmul Huda ${ }^{1}$, A.N.K. Mamun ${ }^{2}$, Md. Rezuanul Islam ${ }^{1}$, Mohammad Abu Hena \\ Mostofa Jamal $^{1}$, and Md. Rezaul Karim ${ }^{1} *$
}

${ }^{1}$ Dept. of Biotechnology and Genetic Engineering, Faculty of Biological Sciences, Islamic University, Kushtia 7003, Bangladesh; ${ }^{2}$ Plant Biotechnology and Genetic Engineering Division, Institute of Food and Radiation Biology, Atomic Energy Commission, Gonakbari, Savar, Dhaka, Bangladesh and ${ }^{3}$ SunUp International School and College, Kushtia 7000, Bangladesh.

*Correspondence: rezaulkarim@btge.iu.ac.bd (Md. Rezaul Karim, Assistant Professor, Dept. of Biotechnology and Genetic Engineering, Faculty of Biological Sciences, Islamic University, Kushtia 7003, Bangladesh).

\begin{abstract}
Medicinal plants are one of the most vital natural resources, but many of them are currently endangered due to habitat loss. Consequently, it is critical to emphasize the importance of using micropropagation techniques for mass propagation of plantlets on a commercial scale, in addition to germplasm conservation and distribution. Nodal explants and shoot tips were expunged from 15 days of the explant by aseptic seedlings, an effective, quick, and better in vitro plant regeneration procedure for Vitex negundo L. has been developed. The recent study was considered to develop an in vitro procedure for the regeneration of $V$. negundo L., a traditional medicinal plant. Nodal segments and shoot tips were cultivated on MS medium enhanced with numerous plant growth regulators. For multiple shoots and root regeneration, various cytokinins were examined. 6-benzylaminopurin (BAP), kinetin (Kin), and 1H-indole-3-butanoic acid (IBA) were all tested as a supplement to Murashige and Skoog (MS) medium including auxin phytohormone, such as Indole acetic acid (IAA) and 1naphthaleneacetic acid (NAA). The furthermost effective surface sterilization treatment for explants of $V$. negundo has been found $0.1 \% \mathrm{HgCl}_{2}$ for 8 minutes. In all treatments, multiple shoots were collected from shoot tips and nodal segments. In MS media added with $2.0 \mathrm{mg} / \mathrm{l}$ BAP, the most shoots were seen in $V$. negundo. Furthermore, $V$. negundo regeneration shoots rooted effectively in half MS containing $1.0 \mathrm{mg} / \mathrm{l} \mathrm{IBA}$. Finally, proliferated plantlets were effectively adapted in soil, where they grew normally without morphological anomalies and had a survival rate of 92 percent.
\end{abstract}

Keywords: In vitro regeneration, Medicinal plant, Vitex negundo, Phytohormone, and Growth regulators.

\section{INTRODUCTION:}

Tissue culture of the plant is an in vitro approach that has appeared as a promising means of propagation and enhancing genomic variety for plant enhancement, and it is used in a variety of industries including agriculture, horticulture, and forestry (Nitish and Reddy, UniversePG I www.universepg.com
2011). Plant tissue culture is the process of developing plant components in an artificial medium so that they can regenerate into new plants. In 1902, a German scientist named Haberlandt got promising results on in-vitro plant growth, making him the first to put plant tissue culture into practice. The best vital advantage of 
aseptic clonal propagation over traditional methods is the ability to develop a large numeral of plants from a single plant in a short amount of time and space (ZhiQiang et al., 2020).

Micropropagation has been used to propagate a variety of plant species, including several therapeutic plants (Lyndsey et al., 1986; Murashige, 1977). The regeneration of therapeutic plants such as Catharanthus roseus, Cinchona ledgeriana, and Digitalis spp., as well as Rehmannia gluthinosa, Rauvolfia serpentina, and Isoplexis canariensis from the shoot and stem meristems, has shown encouraging results. (Paek et al., 1995; Perez et al., 2002; Salma et al., 2008). The high quality of such medicinal plants could be capable to fulfill both the desires of our pharma companies and our basic needs (Wenle et al., 2020). V. negundo (Linn.) is a well-known traditional medicinal plant with a wide range of pharmacological properties (Yo-gendra et al., 2020). The plant includes a wealth of phytochemicals or secondary metabolites from root to fruit, giving it an unmatched range of medical applications (Neha et al., 2021). The current study deals with the comparative performances of a variety of cytokinins including IBA, BAP, and Kinwere all tested singly or in numerous mixtures to MS medium with also the various combination of NAA, and IAA on the in vitro revival of root and shoot by using shoot tips and nodal segmentsof $V$. negundo by successful restoration plants into field environments.

\section{MATERIALS AND METHODS:}

2.1 Explants preparation and inoculation - The explant source was $V$. negundo, which was found from a commercial field in Gulshan in the Dhaka district, Bangladesh. The extraneous elements of the gathered materials, such as mature shoots and leaves, were eliminated. The remaining shoot segments were split into nodal segments of a manageable length $(3-4 \mathrm{~cm})$ and kept in a separate conical flask. The com-ponents were first rinsed under running water, then put in a conical flask filled with purified water and a few droplets of "Tween 20" and washed for 10 minutes while shaking constantly. To remove all residues of the foregoing substances, the second washing was done with an advanced change of distilled water. For surface sterilization, the selected explants were rinsed with $70 \%$ ethyl alcohol followed by washing with DW. To UniversePG I www.universepg.com maintain appropriate time for contamination-free culture, surfaces were disinfected with $0.1 \% \mathrm{HgCl}_{2}$ solution for varied times $(6,8$, and 10 minutes). After that, they were washed in sterile DW used for 10 minutes, resulting in 4-5 changes. It was detected that sterilizing shoot tips for 8 minutes with $0.1 \% \mathrm{HgCl}_{2}$ was beneficial. Explants were properly inoculated in culture glass tubes with agar gelled nutritional media supplied with various hormone doses. During inocul-ation, extra caution was needed to confirm that the explants penetrated but did not drop into the medium.

2.2 Nutrient Media and culture condition - For shoot regeneration and multiplication, along with root induction, Murashige and Skoog, (1962) media added with numerous quantities and mixtures of growth regulators was utilized. The $\mathrm{pH}$ generally adjusted to 5.06.0 of the medium before autoclaving. As a solidifying or gelling agent, agar was usually used in the generation of semisolid (or solid) tissue culture medium. $7 \mathrm{gm}(0.7 \%)$ agar was added to the present culture medium. Autoclaving at $1.05 \mathrm{~kg} / \mathrm{cm} 2$ pressure used for 20 minutes at $121{ }^{\circ} \mathrm{C}$ disinfected the culture vessels. Inoculated culture containers were situated in a growth chamber, which provided a unique cultural environment. In the growing chamber, the vessels were arranged on the shelves of a cabinet. All cultures were maintained in a growth chamber with 40 -watt white fluorescent tubes installed $30-40 \mathrm{~cm}$ away from the culture shelves. The cultures were kept at $26^{\circ} \mathrm{C}$ for 16 hours with a light power of 1500 lux (about) emitted from fluorescent tubes. Each day, the reactivity to the culture vessels was measured.

\subsection{Shoot initiation and propagation from nodal segments and shoot tips - In this investigation, nodal segments and shoot tips of $V$. negundo were cultured on MS media containing various concentrations of BAP and Kinetin $(0.5,1.0,2.0,3.0 \mathrm{mg} / \mathrm{l})$. Furthermore, for shoot development in this experiment, various proportions of BAP $(1.0,2.0,3.0,5.0 \mathrm{mg} / \mathrm{l})$ in con- junction with NAA $(0.1,0.2,0.5 \mathrm{mg} / \mathrm{l})$ and Kinetin $(1.0,2.0,3.0,5.0 \mathrm{mg} / \mathrm{l})$ in mixture with NAA $(0.5$ and $0.1 \mathrm{mg} / \mathrm{l})$ were utilized.}

2.4 Subculture - During culturing, different amounts of 2,4-D $(0.5,1$, and $1 \mathrm{mg} / \mathrm{l})$ were used, along with varying doses of $\operatorname{BAP}(2.0,3.0 \mathrm{mg} / \mathrm{l})$. 
2.5 Root initiation and multiplication - For root induction from micro-cutting of in vitro regenerated shoots of $V$. negundo, different proportions of NAA $(0.1,0.5,1$ and $2 \mathrm{mg} / \mathrm{l})$ and $\operatorname{IBA}(0.1,0.5,1$, and $2 \mathrm{mg} / \mathrm{l})$ in half-strength MS medium and $\mathrm{MS}_{0}$ medium were used.

\subsection{Acclimatization and transfer of plantlets to soil -} The regenerated explants were regarded appropriate for soil transfer after establishing a considerable root system. The growing plants were carefully excised from the culture jars. The roots of the plantlets were carefully rinsed under running tap water to eliminate any agar that had stuck to the root zone. They were immediately placed in small polythene bags with a 1:1:1 mixture of sand, compost, and soil after being washed. The plantlets in pots were enclosed with polythene bags to prevent sudden deformation. Interior sides of this bag were sprayed with water each 24 hours to keep high humidity around the growing plants. The plantlets were gradually vulnerable to the outside normal environment by perforating the polythene envelopes, which were then removed after seven days. By this point, the plantlets have embedded them in the soil. They were eventually relocated to a test field.

2.7 Statistical analysis - All of the tests were repeated three times, with each treatment receiving an average of 25 replicates. SPSS ver. 16 (SPSS Inc., Chicago, USA) were used to perform statistical calculations of the data. DMRT (Duncan's multiple range test) was used to determine the significance of variations between means at $\mathrm{P} \leq 0.05$. The results of the three experiments are reported as means and standard deviations. Data were collected using the following parameters and the methods for data collection are given below:

\section{i) For shoot induction}

\section{a) Percentage of explants induced shoots}

After the needed days of culture, data on various parameters from various treatments of shoot proliferation were recorded. The subsequent method was used to compute the percentages of explants that developed adventitious shoots.

Explants induced shoot $(\%)=\frac{\text { Number of culture induced shoot }}{\text { Total number of explants inoculated }} \times 100$

UniversePG I www.universepg.com

\section{b) Shoots number per plantlet}

After the required days of culture, the shoot numbers of each explant were calculated. The subsequent method was used to calculate the mean number of adventitious shoots for each explant.

Mean number of shoot $=$ Total number of shoot/Quantity of regenerated explants

\section{c) Length of lengthiest shoot}

For each explant, the length of the lengthiest shoot was measured on a cm-scale. The subsequent calculation was used to decide the average length of the shoot.

The average length of shoot $=$ Total length of Shoot/number of shoot

\section{ii) For root induction}

\section{a) Percentage of explants induced roots}

The frequency of shoots induced to develop roots was calculated by using the following formula:

Frequency of shoots induced roots $=\frac{\text { Number of culture induced root }}{\text { Totalnumber of explants inoculated }} \times 100$

\section{b) Number of roots per shoot}

After the required days of culture, the number of roots per shoot was calculated. Using the similar technique as for the number of shoots per explants, the mean numbers of roots and SE per shoot were computed.

\section{c) Mean length of the root}

For each shoot, the average length of the longest root was measured in centimeters. As previously stated, the average length of the root was computed.

The average length of the root $=\frac{\text { Total length of root }}{\text { Total number of observation }}$

\section{RESULTS}

\subsection{Standardization of explant (Vitex negundo L.) surface sterilization}

After cutting into suitable size the nodal segments and shoot tips of $V$. negundo were washed with the continuous flowing of tap water for $20 \mathrm{~m}$ and then treated with antiseptic (4-5 drops liquid soap along with 2-3 drops of Tween-20) and then again washed with $\mathrm{ddH}_{2} \mathrm{O} . \mathrm{HgCl}_{2}$ was utilized as a surface sterilant for the plant used in this investigation. After one week of sterilization and inoculation it was detected that, when the experimented plant parts were treated with $0.1 \%$ $\mathrm{HgCl}_{2}$ for 8 minutes, $95 \%$ of $V$. negundo L. explants were found contamination-free and healthy also. Ex- 
plants treated for a longer time (8-10 minutes), causes no contamination but partial or complete tissue killing was observed $(\mathbf{S}-\mathbf{1})$.

\subsection{Micropropagation through manifold shoot initiation and subsequent development from shoot tip and nodal part of $V$. negundo}

\subsubsection{Shoot Multiplication through Shoot Tip} Culture - Shoot tips approximately $1-2 \mathrm{~cm}$ in size were obtained from field-grown plants and cultivated in MS medium with various doses and mixtures of plant growth regulators (cytokinins and auxins) to determine the best culture media for the multiplication of shoot (Shahen et al., 2019).

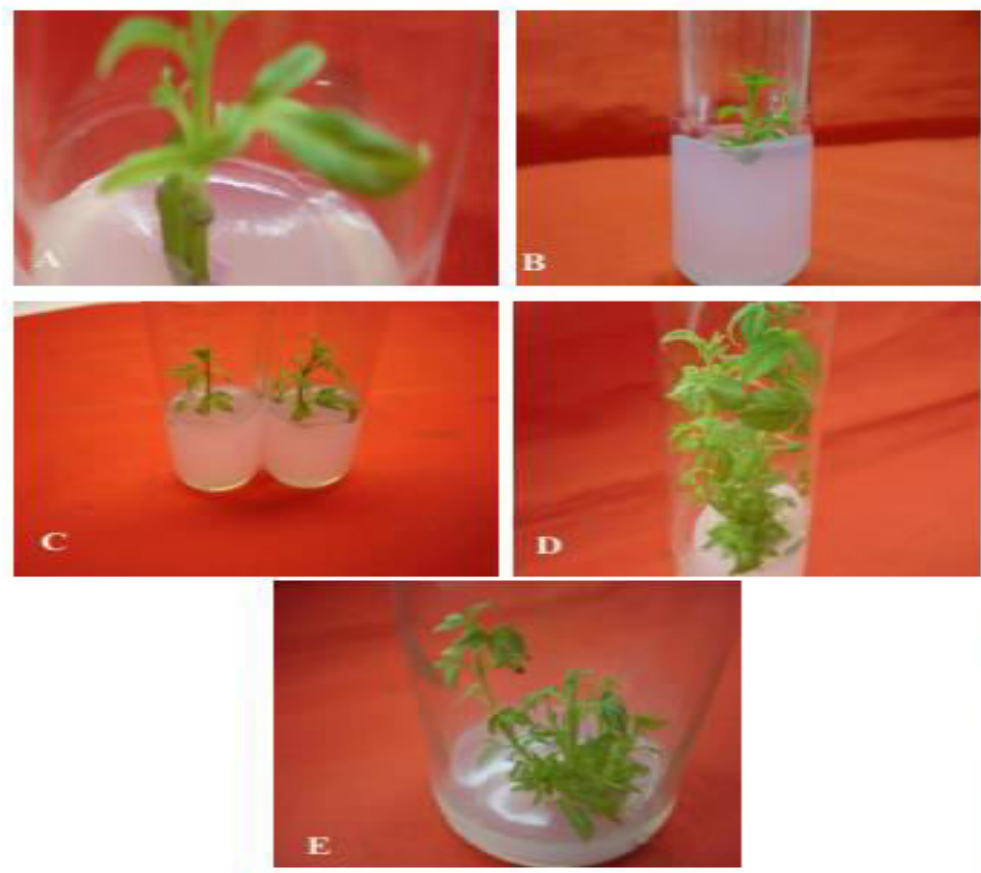

\subsubsection{Effects of diverse concentrations of BAP and} Kinetin on shoot initiation

Shoot tips were cultivated on MS media added with different doses of BAP, Kinetin $(0.5,1.0,2.0,3.0$ $\mathrm{mg} / \mathrm{l})$ in this experiment. After 20-25 days, the cultured explants began to develop. In the instance of BAP, the proportion of cultures that responded to shoot formation at various levels ranging from 33.3 to $73.3 \%$. When explants were cultivated in media addedby 3.0 $\mathrm{mg} / \mathrm{l} \mathrm{BAP}$, the greatest percentage of shoot induction was observed (Fig 1A-1C, 1F). Conversely, the response of shoot formation to different levels of Kinetin ranged from 33.3 to $73.3 \%$, with the greatest response observed at $1.0 \mathrm{mg} / \mathrm{l}$ concentration (Table 1).

Fig 1: Regeneration of $V$. negundo L. by using shoot tip through the in-vitro process. (A) Induction of shoot tip of V. negundo L. on MS culture medium; (B-C) Shoot development; (D) Using shoot tip explant from V. negundo $\mathrm{L}$ for the induction of manifold shoots on MS medium containing 2mg/l BAP, Production of multiple shoots; (E) Development of multiple shoots; (F) Effects of different measures of Cytokinins (BAP and Kinetin); (G) Effects of different combinations of BAP and Kinetin on shoot length in $V$. negundo L.

3.2.1.2 Effects of cytokines on the stimulation of multiple Shoots in $V$. negundo

Effects of diverse concentrations of BAP and Kinetin - The number of shoots enlarged progressively in all mediums supplemented with variable BAP and Kinetin $(0.5,1.0,2.0,3.0 \mathrm{mg} / \mathrm{l})$ concentrations through the culture period. The results of the records collected after 45 days of culture are provided in (S-2). On MS medium comprising $2.0 \mathrm{mg} / \mathrm{l}$ of BAP, the highest UniversePG I www.universepg.com

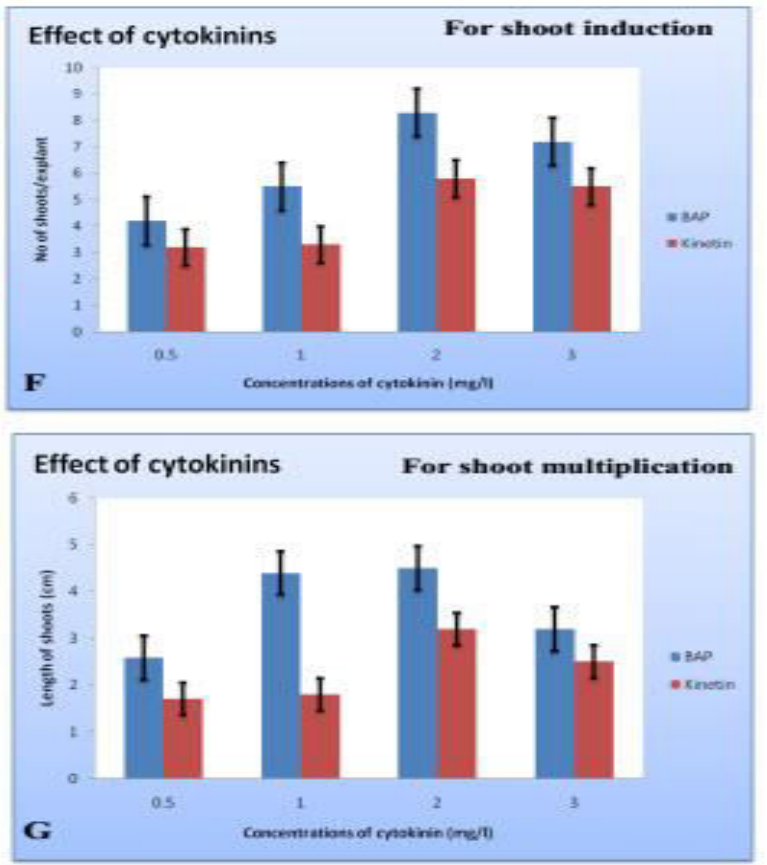

response for shoot expansion was seen, with a frequency of 8.3 shoots per explant growing to a height of $4.5 \mathrm{~cm}$. The medium including $0.5 \mathrm{mg} / 1$ of BAP,the lowest percentage $(46.6 \%)$ was discovered. In a medium having $2.0 \mathrm{mg} / \mathrm{l}$ of Kinetin, $73.3 \%$ of cultures responded, with an average of 5.8 shoots and $3.2 \mathrm{~cm}$ in length (Fig 1D-1F, 1G). Besides, the medium addedby $0.5 \mathrm{mg} / \mathrm{l} \mathrm{Kinetin}$ showed the lowest response $(\mathbf{S}-\mathbf{2})$. 
Table 1: Effects of Diverse Concentrations of Cytokinins on shoot initiation from shoot tip.

\begin{tabular}{|c|c|c|c|c|c|c|}
\hline \multicolumn{2}{|c|}{$\begin{array}{c}\text { Treatment } \\
(\mathbf{m g} / \mathbf{l})\end{array}$} & $\begin{array}{c}\text { Explants number } \\
\text { for inoculation }\end{array}$ & $\begin{array}{c}\text { \% of explants } \\
\text { producing the shoot }\end{array}$ & $\begin{array}{c}\text { Days to shoot } \\
\text { initiation }\end{array}$ & $\begin{array}{c}\text { Shoot number } \\
\text { Average)/explant }\end{array}$ & $\begin{array}{c}\text { The average length } \\
\text { of the shoot (cm) }\end{array}$ \\
\hline \multirow{3}{*}{ BAP } & 0.5 & 25 & 46.6 & 9 & $0.60 \pm 0.51$ & $0.58 \pm 0.1$ \\
\cline { 2 - 7 } & 1.0 & 20 & 53.3 & 7 & $0.71 \pm 0.13$ & $1.12 \pm 0.19$ \\
\cline { 2 - 7 } & 2.0 & 25 & 68.3 & 6 & $0.72 \pm 0.22$ & $1.1 \pm 0.18$ \\
\cline { 2 - 7 } & 3.0 & 30 & 80 & 6 & $1.5 \pm 0.30$ & $1.5 \pm 0.42$ \\
\hline \multirow{3}{*}{ Kinetin } & 0.5 & 35 & 33.3 & 11 & $1.1 \pm 0.29$ & $0.78 \pm 0.19$ \\
\cline { 2 - 7 } & 1.0 & 25 & 73.3 & 7 & $1.12 \pm 0.18$ & $1 \pm 0.19$ \\
\cline { 2 - 7 } & 2.0 & 15 & 68.3 & 6 & $0.85 \pm 0.28$ & $1.2 \pm 0.31$ \\
\cline { 2 - 7 } & 3.0 & 30 & 46.6 & 10 & $1.1 \pm 0.21$ & $0.98 \pm 0.15$ \\
\hline
\end{tabular}

\section{Effects of various levels of BAP with Kinetin}

In vitro developed shoots were individually cultured by MS medium enhanced with three concentrations and mixtures of BAP with Kinetin. Among the three concentrations highest (80\%) and the lowest (53.3\%) percentage of multiple shooting were observed in the medium added with $0.5 \mathrm{mg} / \mathrm{l} \mathrm{BAP}+1.0 \mathrm{mg} / \mathrm{l}$ Kinetin and $1.0 \mathrm{mg} / \mathrm{l} \mathrm{BAP}+0.5 \mathrm{mg} / \mathrm{l} \mathrm{Kinetin}$. After 90 days of cultivation, data was obtained. Furthermore, the cultured plantlets in the mixture comprising $0.5 \mathrm{mg} / \mathrm{l}$ of $\mathrm{BAP}+1.0 \mathrm{mg} / \mathrm{l}$ of Kinetin had the largest average size of shoots $(3.2 \mathrm{~cm})(\mathbf{S}-\mathbf{2})$.

\subsubsection{Effects of cytokinins with auxins on the rege-} nerating of multiple shoots

For shoot development, diverse BAP concentrations $(1.0,2.0$, and $3.0 \mathrm{mg} / \mathrm{l})$ in mixture with NAA $(0.1,0.2$, and $0.5 \mathrm{mg} / \mathrm{l})$ were utilized, along with diverse concentrations of Kinetin $(1.0,2.0,3.0$, and $5.0 \mathrm{mg} / \mathrm{l})$ in mixture with NAA $(0.5$ and $0.1 \mathrm{mg} / \mathrm{l})(\mathbf{S}-3)$. Among the various concentrations and mixtures of cytokinins and NAA, the maximum active implementation for enhancing multiple shootswas found on $3.0 \mathrm{mg} / \mathrm{l} \mathrm{BAP}$ $+0.1 \mathrm{mg} / \mathrm{l}$ NAA, with an average of $93.3 \%$ responding to shoot formation, including the lengthiest shoot length $(3.9 \mathrm{~cm})$ and the most shoots each culture (7.6) (Table 2).

Table 2: Shoot Multiplication through shoot tip.

\begin{tabular}{|l|c|c|c|c|}
\hline \multicolumn{2}{|c|}{ Treatment (mg/l) } & $\begin{array}{c}\text { \% of explants producing } \\
\text { the shoot }\end{array}$ & $\begin{array}{c}\text { Average number of } \\
\text { the shoot/explant }\end{array}$ & $\begin{array}{c}\text { The average length of the } \\
\text { shoot (cm) }\end{array}$ \\
\hline BAP & 2.0 & 90 & $8.3 \pm 1.14$ & $4.5 \pm 0.48$ \\
\hline Kinetin & 2.0 & 73.3 & $5.8 \pm 0.42$ & $3.2 \pm 0.31$ \\
\hline BAP+NAA & $3.0+0.1$ & 93.3 & $7.6 \pm 0.79$ & $3.9 \pm 0.32$ \\
\hline BAP+IAA & $2+0.1$ & 86.6 & $6.0 \pm 0.61$ & $4.2 \pm 0.51$ \\
\hline Kinetin+NAA & $3.0+0.1$ & 87 & $5.8 \pm 0.66$ & $1.94 \pm 0.4$ \\
\hline Kinetin+IAA & $2.0+0.1$ & 73.3 & $5.5 \pm 0.41$ & $1.8 \pm 0.41$ \\
\hline
\end{tabular}

Instead, the medium containing $2.0 \mathrm{mg} / \mathrm{I}$ BAP +0.1 $\mathrm{mg} / \mathrm{l}$ IAA produced the highest proportion $(86.6 \%)$ of culture (Table 2, Fig 3A-3B).

Again, the most successful compositions for multiple shoots induction were observed to be $3.0 \mathrm{mg} / \mathrm{l}$ Kinetin $+0.1 \mathrm{mg} / \mathrm{l}$ NAA, with averages of $87 \%$ culture reacted to shoot formation, including shoot per explant of 5.8 and the average size of shoot $1.94 \mathrm{~cm}$ long in asimilar media. Subsequently 90 days, the culture data were collected (Table 2).
The highest percentage of culture reacted $86.6 \%$ in a medium having $3.0 \mathrm{mg} / \mathrm{l}$ Kinetin $+0.1 \mathrm{mg} / \mathrm{l} \mathrm{IAA}$, with an average quantity of shoots per explant of 5.5 in the similar media. After 90 days of culture, all data were collected (Fig 3C-3D) (S-3).

\subsubsection{Shoot Multiplication through Nodal Segment}

Culture - For the multiplication of shoots, nodal segments of the field-grown plants were cultured on MS medium addedby various concentrations of BAP, Kinetin alone, or in combination with NAA and IAA. 

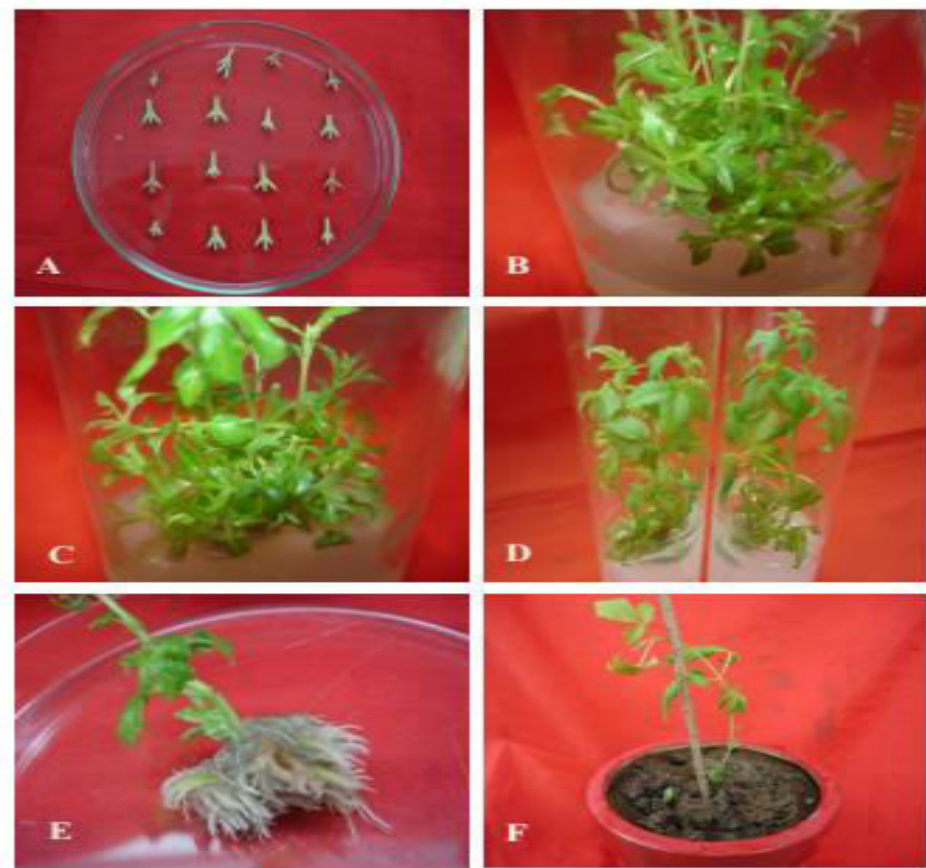
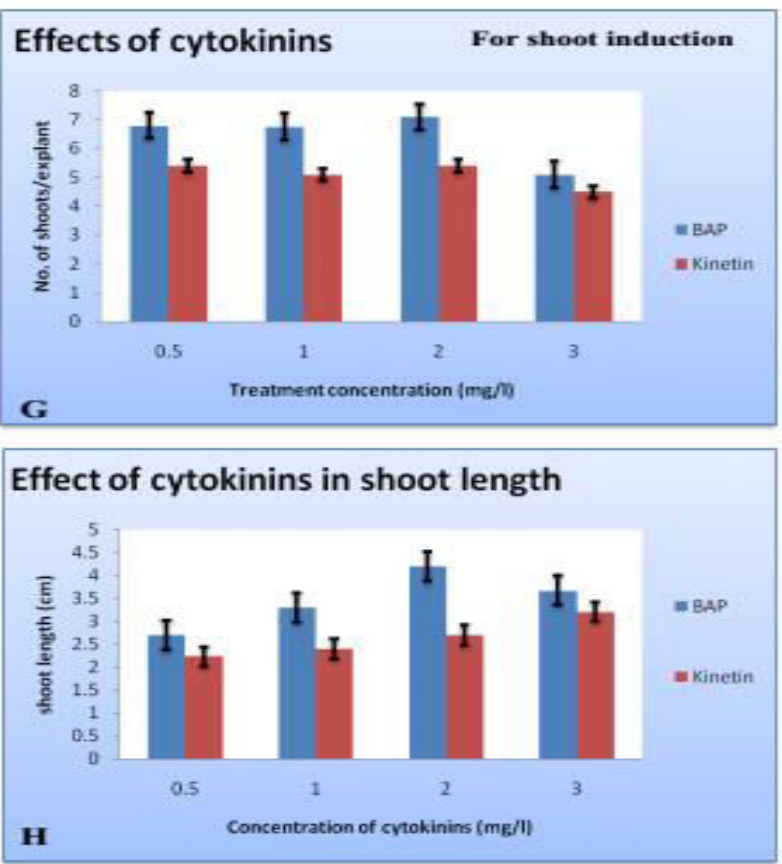

Fig 2: In vitro regeneration of $V$. negundo L. by using nodal segment. (A) The nodal segment of $V$. negundo L. is used as an explant source; (B) Induction of numerous shoots by nodal segment culture; (C) Development of multiple shoots from the nodal segment; (D) Shoot development and elongation from the regenerated shoot (after 9 weeks) of culture; (E) Rooting of in vitro regenerated shoots in V. negundo L; (F) Acclimatized of plantlets; (G) Effects of combinations of BAP and Kinetin on the number of shoot/explant using nodal segment; $(\mathrm{H})$ Effects of different concentrations of BAP and Kinetin on Shoot length of V. negundo.
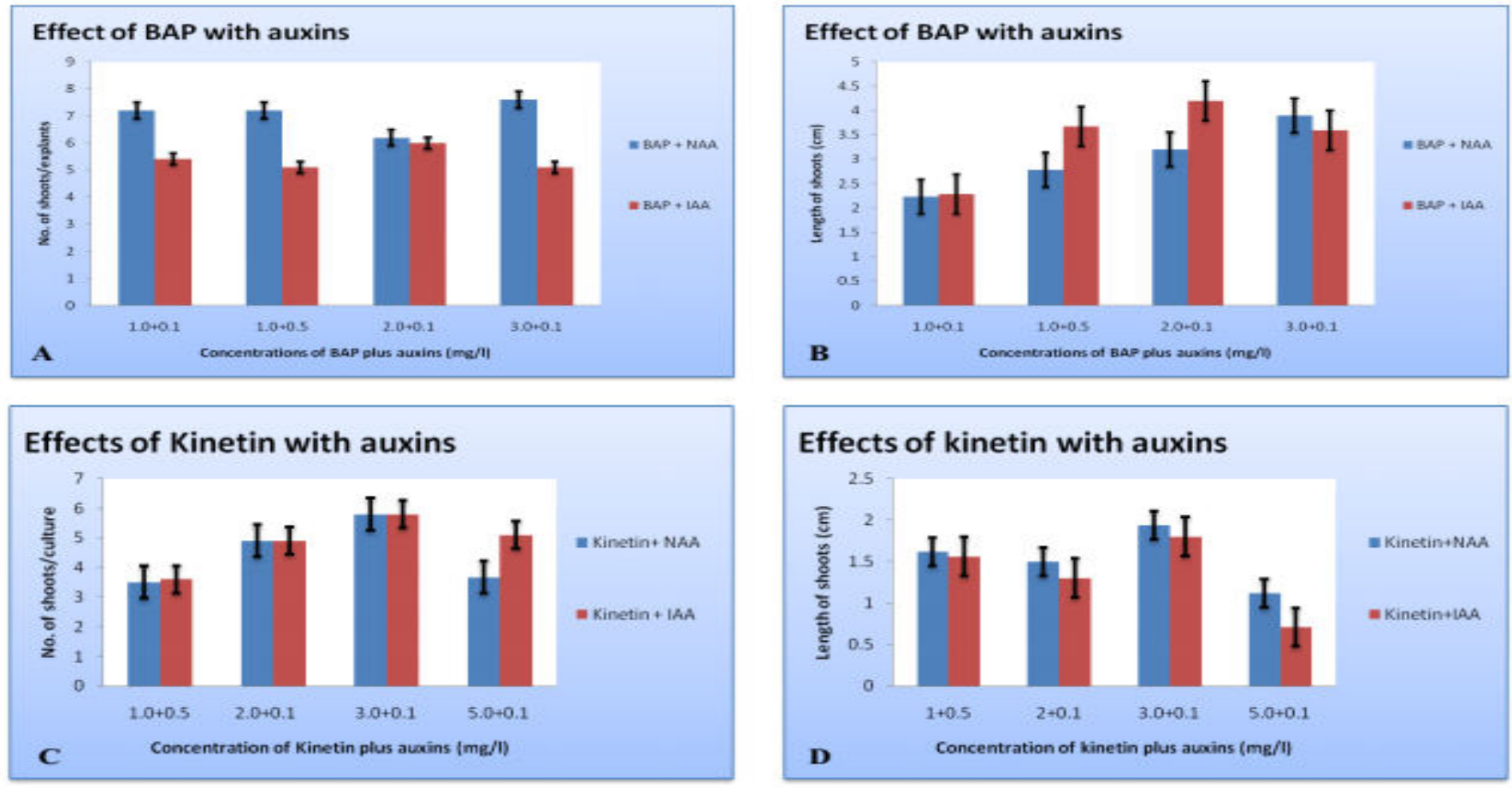

Fig 3: Effect of cytokinin with auxin for in-vitro rejuvenation from shoot tip of $V$. negundoL. (A) Effects of BAP with auxins (IAA and NAA) on the shoot/explant number by using shoot tip, (B) Effects of BAP with auxins (IAA and NAA) on shoot length of V. negundo L, (C) Effects of Kinetin with auxins (IAA and NAA) on the shoot the number of shoot/explant from shoot tip, (D) Effects of Kinetin with auxins (IAA and NAA) on shoot length of $V$. negundo L. 


\subsubsection{Shoot Induction by Diverse Concentration of Cytokinins}

$V$. negundo nodal sections were cultivated on MS media added with diverse concentrations of BAP and Kinetin $(0.5,1.0,2.0$, and $5.0 \mathrm{mg} / \mathrm{l})$ in this research. After 20-25 days, the cultured explants began to develop. Shoot induction efficiencies with BAP added culture range from 33.3 to $87.5 \%$. Furthermore, the cultures that responded to shoot development at various Kinetin concentrations ranged from 33.3 to $68.3 \%$ (Table 3). Explants cultivated in medium added with $2.0 \mathrm{mg} / \mathrm{l}$ BAP demonstrated the utmost percentage of shoot induction, with $87.5 \%$ of explants showing the upper most shoot induction. $2.0 \mathrm{mg} / \mathrm{l}$ Kinetin, conversely, causes the most shoot proliferation, with $68.3 \%$ of explants showing the most shoot induction (Fig 2A-2B, 2G) (Table 3).

Table 3: Effects of Various concentrations of cytokinins on shoot stimulation from the nodal segment.

\begin{tabular}{|c|c|c|c|c|c|c|}
\hline \multicolumn{2}{|c|}{$\begin{array}{c}\text { Treatment } \\
(\mathbf{m g} / \mathbf{l})\end{array}$} & $\begin{array}{c}\text { Number of } \\
\text { explants inoculated }\end{array}$ & $\begin{array}{c}\text { \% of explant } \\
\text { producing the shoot }\end{array}$ & $\begin{array}{c}\text { Days to shoot } \\
\text { initiation }\end{array}$ & $\begin{array}{c}\text { Shoot number } \\
\text { (Average)/explant }\end{array}$ & $\begin{array}{c}\text { Length of the shoot } \\
\text { (cm) (Average) }\end{array}$ \\
\hline \multirow{3}{*}{ BAP } & 0.5 & 30 & 33.3 & 7 & $0.50 \pm 0.21$ & $0.99 \pm 0.22$ \\
\cline { 2 - 7 } & 1.0 & 20 & 53.3 & 6 & $0.70 \pm 0.13$ & $1.12 \pm 0.19$ \\
\cline { 2 - 7 } & 2.0 & 35 & 87.5 & 8 & $1.2 \pm 0.21$ & $1.8 \pm 0.42$ \\
\cline { 2 - 7 } & 3.0 & 25 & 68.3 & 9 & $0.72 \pm 0.65$ & $1.12 \pm 0.12$ \\
\hline \multirow{3}{*}{ Kinetin } & 0.5 & 25 & 33.3 & 10 & $1.3 \pm 0.29$ & $0.72 \pm 0.15$ \\
\cline { 2 - 7 } & 1.0 & 30 & 46.6 & 8 & $1.12 \pm 0.18$ & $0.98 \pm 0.19$ \\
\cline { 2 - 7 } & 2.0 & 20 & 68.3 & 7 & $1.5 \pm 0.28$ & $1.2 \pm 0.31$ \\
\cline { 2 - 7 } & 3.0 & 30 & 53.3 & 6 & $0.71 \pm 0.1$ & $1.0 \pm 0.15$ \\
\hline
\end{tabular}

Table 4: Shoot Multiplication through the nodal segment.

\begin{tabular}{|c|c|c|c|c|}
\hline \multicolumn{2}{|c|}{ Treatment(mg/l) } & $\begin{array}{c}\text { \% of explants producing the } \\
\text { shoot }\end{array}$ & $\begin{array}{c}\text { Shoot number } \\
\text { (Average)/explant }\end{array}$ & $\begin{array}{c}\text { Length of the } \\
\text { shoot(cm)(Average) }\end{array}$ \\
\hline BAP & 1.0 & 87 & $7.1 \pm 0.68$ & $4.2 \pm 0.51$ \\
\hline Kinetin & 2.0 & 73.3 & $5.4 \pm 0.52$ & $2.7 \pm 0.17$ \\
\hline BAP+NAA & $3.0+0.1$ & 93.3 & $8.5 \pm 0.52$ & $3.6 \pm 0.38$ \\
\hline BAP+IAA & $2+0.1$ & 86.6 & $6.8 \pm 0.18$ & $4.37 \pm 0.45$ \\
\hline Kinetin+NAA & $3.0+0.1$ & 90 & $7.2 \pm 0.23$ & $4.3 \pm 0.23$ \\
\hline Kinetin+IAA & $2.0+0.1$ & 60 & $6.2 \pm 0.51$ & $4.1 \pm 0.41$ \\
\hline
\end{tabular}

\subsubsection{Effects of Different Concentrations of Cyto- kinins on Shoot multiplication}

Effects of BAP and Kinetin variable concentrations on nodal segment - Nodal segments were used for shoot multiplication by diverse BAP and Kinetin (0.5, $1.0,2.0$, and $3.0 \mathrm{mg} / \mathrm{l}$ ) concentrations. The outcomes of 45 days of culture are presented in $\mathbf{S}-\mathbf{4}$. MS media added with $2.0 \mathrm{mg} / \mathrm{l}$ BAP had the best growth response (93.3\%), including an average number of shoots per explant of 7.1 and an average size of shoots of $4.2 \mathrm{~cm}$ long. Instead, culture was reacted about $86.6 \%$ in a medium containing $2.0 \mathrm{mg} / \mathrm{l}$ Kinetin, along with the highest average shoots number (5.4) per explant and the average size of the shoots $(3.2 \mathrm{~cm}$ ) (Fig $2 \mathrm{C}$, and 2H).

UniversePG I www.universepg.com
Effects of various BAP and Kinetin concentrations The medium including $0.5 \mathrm{mg} / \mathrm{l} \mathrm{BAP}+1.0 \mathrm{mg} / 1$ Kinetin had the highest percentage of culture responses $(86.6 \%)$ of the three BAP+ Kinetin combinations $(0.5+1.0,1.0+0.5$, and $1.0+1.5)$. In a medium having $1.0 \mathrm{mg} / \mathrm{l} \mathrm{BAP}+1.5 \mathrm{mg} / 1$ Kinetin, however, the lowest $(60 \%)$ percentage of culture was responded to. Every combination resulted in many shoots. $\mathbf{S}-\mathbf{4}$ presents the results.

Effects of Cytokinins with auxin on induction of multiple shoot - In the present study, various concentrations of BAP $(1.0,2.0,3.0 \mathrm{mg} / \mathrm{l})$ and Kinetin (1.0, $2.0,3.0 \mathrm{mg} / \mathrm{l})$ were combined with varied concentrations of NAA $(0.1$ and $0.5 \mathrm{mg} / \mathrm{l})$ and IAA $(0.1$ and $0.5 \mathrm{mg} / \mathrm{l}$ ) to investigate shoot development (Fig 2C- 
2D) (S-5). With varied concentrations and mixtures of BAP and NAA, the explants cultured in a medium having $3.0 \mathrm{mg} / \mathrm{l} \mathrm{BAP}+0.1 \mathrm{mg} / \mathrm{l} \mathrm{NAA}$ responded with the highest percentage (93.3\%) of culture. Furthermore, when the explants were grown in a medium including $2.0 \mathrm{mg} / \mathrm{l} \mathrm{BAP}+0.1 \mathrm{mg} / \mathrm{l} \mathrm{IAA}$, the largest proportion (86.6 percent) of culture responded. (See Table 4) (Fig 4A). Additionally, the medium added with two compositions, $1.0 \mathrm{mg} / \mathrm{l}$ Kinetin $+0.5 \mathrm{mg} / \mathrm{l} \mathrm{NAA}$ and $3.0 \mathrm{mg} / \mathrm{l}$ Kinetin $+0.1 \mathrm{mg} / \mathrm{l} \mathrm{NAA}$, had the highest percentage of culture response $(90 \%)$. However, in a
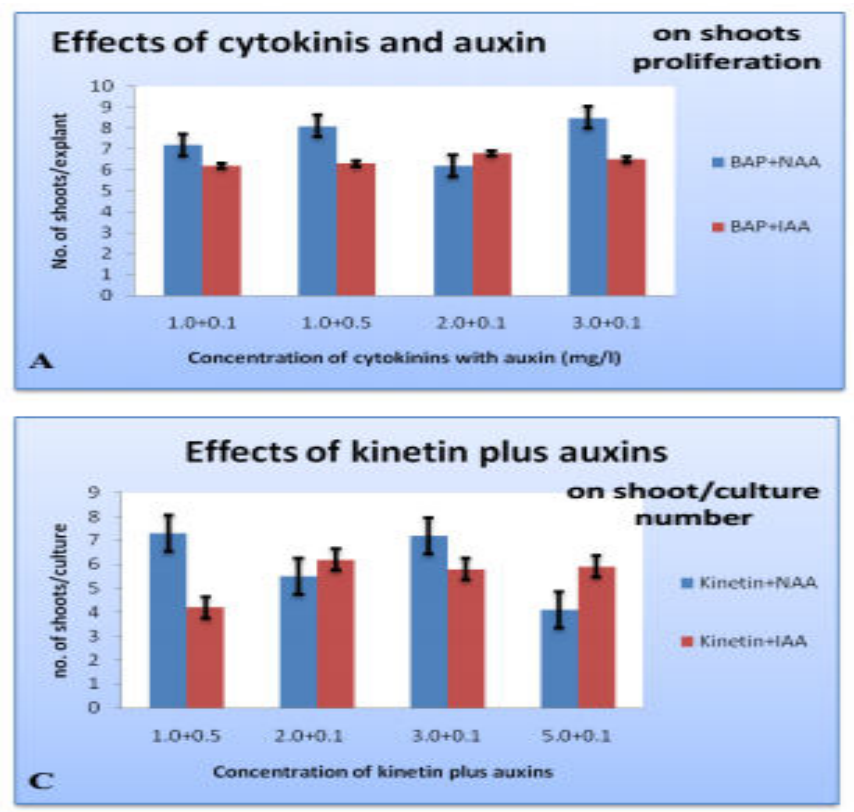

medium containing $3.0 \mathrm{mg} / \mathrm{l}$ Kinetin $+0.1 \mathrm{mg} / \mathrm{l} \mathrm{NAA}$, the maximum average shoots count per explant was 7.2, and the maximum average size of the shoot was $4.3 \mathrm{~cm}$. Furthermore, the medium added with $2.0 \mathrm{mg} / \mathrm{l} \mathrm{Kinetin+}$ $0.1 \mathrm{mg} / \mathrm{l}$ IAA (Table 4) yielded the highest percentage of culture response (80\%) (Fig 2D, 4B) (S-5). From the overall experiments, it is observed that BAP is the best active hormone for multiple shoot initiation and growth in $V$. negundo and the suitable concentration was $2.0 \mathrm{mg} / \mathrm{l} \mathrm{BAP}$.
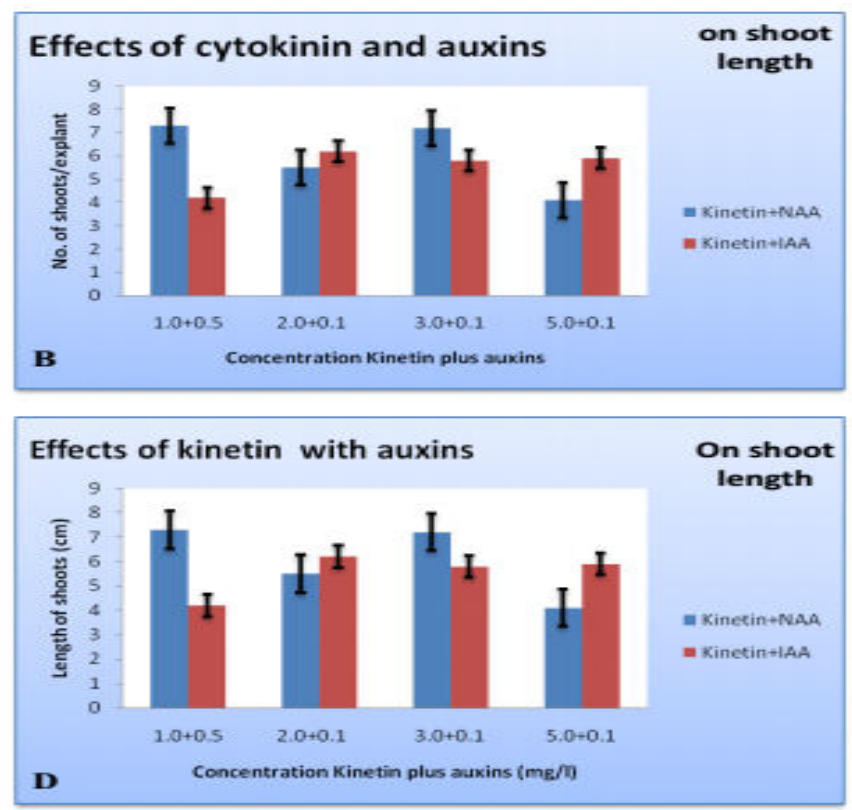

Fig 4: Effect of cytokinin with auxin for in-vitro V. negundo L. regeneration from the nodal segment. (A) Effects of different combinations of cytokinin with auxin (IAA and NAA) on the proliferation of shoots; (B) Effects of different combinations of cytokinin with auxin (IAA and NAA) on shoot length; (C) Effects of cytokinin with auxins (IAA and NAA) on the shoot culture; (D) Effects of cytokinin with auxins (IAA and NAA) on the length of the shoot in $V$. negundo L.

Table 5: Effects of diverse concentrations and mixtures of 2,4-D with BAP on multiple shoot proliferation of $V$. negundo $\mathrm{L}$.

\begin{tabular}{|c|c|c|c|c|c|}
\hline \multicolumn{2}{|c|}{ Growth regulator } & \multirow{3}{*}{$\begin{array}{l}\text { No. of explants } \\
\text { inoculated }\end{array}$} & \multirow{3}{*}{$\begin{array}{l}\% \text { of explants } \\
\text { producing the shoot }\end{array}$} & \multirow{3}{*}{$\begin{array}{c}\text { Shoot number } \\
\text { (Average)/explant }\end{array}$} & \multirow{3}{*}{$\begin{array}{l}\text { Length of the shoot } \\
\text { (cm) (Average) }\end{array}$} \\
\hline Pre-culture & Sub-culture & & & & \\
\hline BAP & $\mathrm{BAP}+2,4-\mathrm{D}$ & & & & \\
\hline \multirow{2}{*}{2.0} & $2.0+0.5$ & 8 & 62.5 & $5.21 \pm 0.53$ & $3.65 \pm 0.62$ \\
\hline & $2.0+1.0$ & 8 & 62.5 & $4.6 \pm 0.66$ & $4.0 \pm 0.74$ \\
\hline \multirow[t]{2}{*}{3.0} & $3.0+0.5$ & 8 & 75 & $6.1 \pm 0.67$ & $4.0 \pm 0.84$ \\
\hline & $3.0+1.0$ & 8 & 87.5 & $5.34 \pm 0.71$ & $3.9 \pm 0.72$ \\
\hline BAP & BAP & & & & \\
\hline \multirow{2}{*}{2.0} & 2.0 & 8 & 75 & $6.22 \pm 0.94$ & $4.1 \pm 0.31$ \\
\hline & 3.0 & 8 & 87.5 & $6.09 \pm 0.74$ & $4.2 \pm 0.24$ \\
\hline \multirow{2}{*}{3.0} & 2.0 & 8 & 62.5 & $5.66 \pm 0.41$ & $4.1 \pm 0.56$ \\
\hline & 3.0 & 8 & 87.5 & $6.82 \pm 0.41$ & $4.3 \pm 0.77$ \\
\hline
\end{tabular}


3.2.3. Root induction - For root stimulation from micro-cutting of in vitro proliferate shoots of $V$. negundo, several concentrations of NAA $(0.1,0.5,1$ and $2 \mathrm{mg} / \mathrm{l})$ and IBA $(0.1,0.5,1$ and $2 \mathrm{mg} / \mathrm{l})$ in MS medium including half-strength and $\mathrm{MS}_{0}$ media were used (Table 6). $\mathrm{MS}_{0}$ medium was employed for root initiation in this experiment. Induction of root is relatively low in such medium. In diverse NAA and IBA concentrations containing media ranging from 0.1 to
$2.0 \mathrm{mg} / \mathrm{l}$, about $93.3 \%$ of shoots promote rooting. In a medium involving $0.5 \mathrm{mg} / \mathrm{l} \mathrm{NAA}$, the best response of root stimulation in each culture was detected. In a medium including $1.0 \mathrm{mg} / \mathrm{l} \mathrm{NAA}$, the root's average length was the longest. In IBA, nearly identical results were observed. The best number of root/culture saverage was found 13 in a medium with $0.5 \mathrm{mg} / \mathrm{l} \mathrm{IBA}$, while the longest average size of the root was $2.0 \mathrm{~cm}$ in a medium with 1.0-2.0 mg/l IBA (Table 6, Fig 2E).

Table 6: Effects of various NAA and IBA concentrations in 1/2-strength of the MS medium for rooting of the extended microshoots of $V$. negundo

\begin{tabular}{|c|c|c|c|c|c|c|}
\hline \multicolumn{2}{|c|}{ Treatment(mg/l) } & $\begin{array}{c}\text { Explants number } \\
\text { (inoculated) }\end{array}$ & $\begin{array}{c}\text { \% of explants } \\
\text { producing the shoot }\end{array}$ & $\begin{array}{c}\text { Days to root } \\
\text { responded }\end{array}$ & $\begin{array}{c}\text { Root number } \\
\text { (Average) /culture }\end{array}$ & $\begin{array}{c}\text { The average length } \\
\text { of the root (cm) }\end{array}$ \\
\hline \multicolumn{2}{|c|}{ MS 0 } & 15 & 53.3 & 15 & $5.6 \pm 0.75$ & $1.7 \pm 0.72$ \\
\hline \multirow{5}{*}{ NAA+1/2MS } & 0.1 & 15 & 80 & 10 & $10.53 \pm 1.1$ & $1.9 \pm 0.86$ \\
\cline { 2 - 8 } & 0.5 & 15 & 87.5 & 9 & $13.5 \pm 1.23$ & $2.0 \pm 0.71$ \\
\cline { 2 - 8 } & 1.0 & 15 & 80 & 12 & $12.8 \pm 0.98$ & $2.2 \pm 0.94$ \\
\hline \multirow{3}{*}{ IBA+1/2MS } & 2.0 & 15 & 73.3 & 14 & $7.89 \pm 0.23$ & $1.9 \pm 0.61$ \\
\cline { 2 - 8 } & 0.1 & 15 & 80 & 16 & $5.42 \pm 0.79$ & $1.6 \pm 0.49$ \\
\cline { 2 - 8 } & 1.0 & 15 & 66.6 & 16 & $14.7 \pm 0.23$ & $2.4 \pm 0.88$ \\
\hline
\end{tabular}

3.2.4. Establishment of regenerated plantlets to field environments - After sufficient root development, the rooted shoots were planted in small poly stacks comprising garden soil, sand, and compost in a 1:1:1 ratio. To maintain the bags moistly, they were covered by plastic film and progressively acclimatized to outdoor conditions. Plantlets resulting from a variation of in vitro cultures were successfully transplanted into the soil. In open-air soil pots, about $92 \%$ of plants survived (Fig 2F).

\section{DISCUSSION:}

For the vast majority of the world's inhabitants, medicinal plants constitute a crucial source of lifesaving medications. There are quite high opportunities for the production of plant-based medicine from in vitro regenerated medicinal plants (Radha et al., 2011). This may be accom-plished using a wide range of techniques, including micropropagation. In the field of forestry and flori-culture, micropropagation is commonly employed. Plant species that are endangered or unusual can also benefit from micropropagation. Tween 20 and $0.1 \%$ mercuric chloride $\left(\mathrm{HgCl}_{2}\right)$ solution were utilized as surface sterilizing agents for various periods in the current research, surface sterilization using $\mathrm{HgCl}_{2}$ has come to light in several studies (Borthakur et al., 2000; Minakshi and Singh, 2017). Treatment of $V$. negundo explants with $0.1 \%$ $\mathrm{HgCl}_{2}$ solution for 8 minutes resulted in contamination-free culture with excellent survival, following the findings. The majority of authors reported that many medicinal plants were highly responded in the MS medium, e.g. Calotropis gigaritea (Roy and De, 1990), Asclepias curassavica (Pramanik and Datta, 1986), Solanum torvum (Jaiswal and Narayan, 1985), Rauvolfia serpentina (Roy et al., 1994), Cephaelisi pecacuanha (Jha and Jha, 1989), Adhatoda vasica (Raageeva and Shahnawaz, 2011), Azadirachta indica (Homen et al., 2017), and so many as well as other medicinal herbs. $2 \mathrm{mg} / \mathrm{l}$ BAP was combined with 0.5 $\mathrm{mg} / \mathrm{l} \mathrm{NAA}$ in this report, which is appropriate for the nodal segment and shoot tip culture from a field-grown plant. The best result was $2 \mathrm{mg} / \mathrm{l}$ BAP. When a medium containing $2 \mathrm{mg} / \mathrm{l} \mathrm{BAP}$ was used, the largest amount of shoots per explant on average was observed from both nodal segments and shoot tips. In Chrysanthemum, (Waseem et al., 2011 and Yesmin et al., 2014) achieved a more or less identical result. Kiran 
and Trevor, (1990) found that BAP $(2.0 \mathrm{mg} / \mathrm{l})$ had a better impact on shoot multiplication. $2.2 \mathrm{mg} / \mathrm{l} \mathrm{BAP}$ was discovered to be the most efficient concentration for shoot tip culture in pear plants (Lane et al., 1979). While the basal MS media, BAP @ 2.5mg/l, and NAA $@ 0.5 \mathrm{mg} / \mathrm{l}$ demonstrated the top response to regeneration via callus induction, with a typical of 5.1 shoot buds per culture in 4-5 weeks (Suvalaxmi et al., 2017).

The highest percentages of shoot propagation were achieved in mediums added with 9.0 M BAP and 0.5 $\mathrm{M}$ indole-3-acetic acid in shoot-tip cultures of Pyrus elaeagrifolia Pallas, an vital gene source for chlorosis resistance and drought in pear rootstock breeding (Ahmed and Hatice, 2015). The utilization of three auxins, when combined with BAP in rose genotypes, revealed that NAA was more successful than IAA or IBA in producing multiple shoots (Pati et al., 2006). Experiments were also conducted to standardize cultured in vitro procedures for widespread dissemination of Woodfordia fruticosa, with explants cultivated on MS medium with the addition of 2, 4- D (1.0 mg/l) and BAP $(0.5 \mathrm{mg} / \mathrm{l})$ producing better results. Excellent results were also obtained using BAP-containing MS media or NAA $(1.0 \mathrm{mg} / \mathrm{l})$ (Vimla Meena and Satish Kumar, 2017). The impact of BAP with NAA on the proliferation of shoots from explants like shoot tips and nodal segments was investigated in this experiment. The medium with $3.0 \mathrm{mg} / \mathrm{l} \mathrm{BAP}+0.1 \mathrm{mg} / \mathrm{l}$ NAA yielded the meanest explants with a certain number of shoots.

Borchetia et al. (2009) discovered that combining BAP and IAA produced the most shoots. In this instance, the most effective composition is $3.0 \mathrm{mg} / \mathrm{l} \mathrm{BAP}+0.1$ $\mathrm{mg} / \mathrm{IAA}$ in MS (medium) for shoot proliferation from shoot tips in addition to nodal segment explants. In this combination, nodal segments produced the largest average total number of shoots, rather than shoot tips. In this research, shoot tips were found to have a larger shooting frequency multiplication than nodal segments in $V$. negundo. When nodal segments and shoot tips were cultured on MS medium that contains BAP and Kinetin in various compositions, here BAP was discovered to superior to Kinetin relating to shoot multiplication. Because of differences in genotypes and explant, various authors may have come up with different conclusions. Nodal segments and shoot tips UniversePG I www.universepg.com were rooted and grown into complete plantlets. Root and shoot development derived from shoots are particularly critical for tissue culture-derived shoot establishment (Sayeed et al., 2015).

To find the optimal root induction strategy, many tests had been completed using a half-strength MS medium added with different amounts of nutrients, such as auxins (NAA, IBA). Farhana et al. (2008) unclosed that the medium with $1.0 \mathrm{mg} / \mathrm{l} \mathrm{IBA}$ produced the most roots. However, Jawahar et al. (2008) investigated that the regenerated shoots were discovered to be effective when rooted on MS media added with $0.5 \mathrm{mg} / \mathrm{l} \mathrm{IBA}$ to induce root from in vitro grown shoots of $V$. negundo. Half-strength MS medium added with $0.5 \mathrm{mg} / \mathrm{l}$ IBA was used to grow rooting shoots (Steephen et al., 2010). Nevertheless, in this inquiry IBA was used alone for rooting, it surpassed other auxins (NAA). In both half-strength, MS mediums with $1.0 \mathrm{mg} / \mathrm{l} \mathrm{IBA}$, the optimal concentration for root development and proliferation was obtained. Dhir et al. (1998) also utilized the same strategy for acclimatization as this investigation. In vitro clonal cultivation, germplasm collection, and dissemination also may assist $V$. negundo, for further research. The new study indicated that acclimatized plants survived at a rate of $92 \%$, which is greater than the previous result (Jawahar et al., 2008).

\section{CONCLUSION:}

This work generated an in vitro protocol for the proliferation of shoots, root induction, and effective adaptation of the medicinal herb $V$. negundo L. For greater frequency shoot multiplication, $\mathrm{HgCl}_{2}$ was utilized to surface sterilize the explants. After treatment in $0.1 \%$ $\mathrm{HgCl}_{2}$ for 8 minutes, over $90 \%$ of explants were found to be free of surface contaminants with minimal tissue injury. To investigate clonal propagative effectiveness, explants were cultivated on MS medium treated with various concentrations and mixtures of cytokines, auxin, and 2,4-D, auxin. The greatest response was seen with $V$. nigundo at $2.0 \mathrm{mg} / \mathrm{l}$ BAP. Moreover, regenerated shoot tips are induced to root in halfstrength MS media supplemented with various doses of NAA and IAA for rooting. A half MS with $2.0 \mathrm{mg} / \mathrm{l}$ IAA yielded enough healthy roots. When the seedlings were transplanted to the soil, more than $92 \%$ of them had effectively acclimatized. This method could be used for both commercial plantlet bulk propagation, 
germplasm preservation, and distribution. Optimization might be taken in the future procedure for greater outcomes.

\section{ACKNOWLEDGMENT:}

The authors are very much thankful to the Department of Biotechnology and Genetic Engineering, Islamic University Kushtia-7003, Bangladesh and Atomic Energy Commission, Savar for research facilities and other logistic supports.

\section{CONFLICTS OF INTEREST:}

The authors declared there is no conflict of interest.

\section{REFERENCES:}

1) Ahmed, A. and Hatice, D. (2015). In vitro shoot proliferation and in vitro and ex vitro root formation of Pyrus elaeagrifolia Pallas. Frontiers in Plant Science, 6(225), 1-8. https://doi.org/10.3389/fpls.2015.00225

2) Borchetia, S., Das S.C., and Das, S. (2009). High multiplication frequency and genetic stability for commercialization of the three varieties of micropropagated tea plants (Camellia spp.). Scientia Horticulturae, 120(4), 544-550. https://doi.org/10.1016/j.scienta.2008.12.007

3) Borthakur, M., Dutt, K., Nath, S.C. and Singh, R. (2004). Micropropagation of Eclipta alba and Eupatorium adenophorum using a single-step nodal cutting technique. Plant Cell, Tissue and Organ Culture, 62(3),239-242.

https://doi:10.1023/A:1006465517666

4) Dhir, S.K., Oglesby, J. and Bhagsari, A.S. (1998). Plant regeneration via somatic embryogenesis, and transient gene expression in sweet potato protoplast. Plant Cell Rep., 17, 665-669. https://doi.org/10.1007/s002990050462

5) Farhana, A., Sayeed, A.H., and Rahima K. (2008). In Vitro Regeneration of Vitex negundo L., a Woody ValuableMedicinal Plant through High Frequency Axillary Shoot Proliferation. Bangladesh J. Sci. Ind. Res. 43(3), 345-352.

6) Haberlandt, G. (1902). kulturversuche mit isolierten pflanzenzellen. Sitzungsber. Akad. Wiss. Wien. Math.Naturwiss. Kl., Abt. J, 111, 69-92. https://users.ugent.be/ pdebergh/his/his2az1.htm

7) Homen, P., Ravindra, K. and Pradip, K.M. (2017). Plant Regeneration by Somatic Embryo- genesis in Azadirachta indica A. Juss. (Neem). International Research J. of Engineering and Technology (IRJET), 4(6), 3212-3217.

8) Jaiswal, V.S. and Narayan, P. (1885). Plantlet regeneration from hypocotyl callus of Solanum torvum Swartz. J. of Plan. Phys., 119(5), 381-383. https://doi.org/10.1016/S0176-1617(85)80001-8

9) Jawahar, M., Ravipaul, S. and Jeyaseelan, M. (2008). In vitro regeneration of $V$. negundo L.- A multipurpose woody aromatic medicinal shrub. Plant Tissue Cult. and Biotechnol., 18(1), 37-42. https://doi:10.3329/ptcb.v18i1.3263

10) Jha, S. and Jha, T.B. (1989). Micropropagation of C. impecacuanha rich. Plant Cell Rep., 8, 437-439. https://doi.org/10.1007/BF0026904

11) Kiran, K.S. and Trevor, A.T. (1990). In vitro propagation of mulberry ( $M$. alba L.) through nodal segments. Scien. Horti., 42(4), 307-320. https://doi.org/10.1016/0304-4238(90)90054-I

12) Lane, W.D. (1979). Regeneration of pear plants from shoot meristem tips. Plant Science Letters, 16(2-3), 337-342. https://doi.org/10.1016/0304-4211(79)90046-4

13) Lyndsey, A. and Withers, P.G.A. (1986). Plant Tissue Culture and Its Agricultural Applications. ( $1^{\text {st }}$ edition), 1- 542.

14) Minakshi, P. and Singh, S.P. (2017). Surface Sterilization for Reducing Microbial Contamination in In Vitro Propagation of Lasora $(C$. Roxb.) Using Nodal Segments. Intern. J. of Curr. Microbiol. and Appl. Sci., 6(8), 836-842. https://doi.org/10.20546/ijcmas.2017.608.106

15) Murashige, T. (1977). Clonal Crops Through Tissue Culture. In: Barz et al. (eds) Plant Tissue Culture and Its Biotechnological Application. Proceedings in Life Sciences. Springer, Berlin, Heidelberg, 392-403. https://doi:10.1007/978-3-642-66646-9 33

16) Murashige, T. and Skoog, F. (1962). A revised medium for rapid growth and bio assays with tobacco tissue culture. Phys.Plant.,15(3), 473-497. https://doi.org/10.1111/j.13993054.1962.tb08052.x

17) Neha, B., Jannavi, R. and Sukumaran, P. (2021). Phyto-pharmacological and Biological Aspects of Vitex negundo Medicinal Plant - A Review. J. of Pharmaceut. Res. Int., 33 (29A), 17-32. http://doi:10.9734/JPRI/2021 /v33i29A31562 
18) Nitish, K. and Reddy, M.P. (2011). In vitro plant propagation: a review. J. of For. Sci., 27(2), 61-72. http://www.koreascience.or.kr/article/JAKO20112 2350102027.pdf

19) Paek, K.Y., Sung, N.S and Park, C.H. (1995). Micropropagation of Rehmanniaglutinosa as medicinal plant by shoot tip and root segment culture. Acta Horticulturae, 390(15), 113-120. https://doi.org/10.17660/ActaHortic.1995.390.15

20) Perez, B.P., Seitz, H.U. and Gavidia, I. (2002). A protocol for rapid micropropagation of endangered Isoplexis. In Vitro Cellular \& Developmental Biology. Plant, 38, 178-82. https://doi:10.1079/1VP2001282

21) Pramanik, T.K. and Datta, S.K. (1986). Plant regeneration and ploidy variation in culture derived plants of Asclepiascuraravical L. Plant Cell Reports, 5(3), 219-222. https://doi:10.1007/BF00269124

22) Pratap, K.P., Anil, S. and Paramvir, S.A. (2006). In vitro propagation of rose - a review. Biotechnology Advances, 24(1), 94-114.

https://doi:10.1016/j.biotechadv.2005.07.001

23) Raageeva, B. and Shahnawaz, M.D. (2011). Plant regeneration from nodal explants of Adhatoda vasica Nees. J. of Medicinal Plants Research, 6(7), 1229-1233, https://doi:10.5897/JMPR11.1055

24) Radha, R.K., Divya, K., and Seeni, S. (2011). In vitro Propagation of Rubiacordifolia Linn., A Medicinal Plant of the Western Ghats. International Journal of Botany, 7, 90-96. https://doi:10.3923/ijb.2011.90.96

25) Roy, A.T. and De, D.N. (1990). Tissue culture and plant regeneration from immature embryo explants of bioenergy society of India, New Delhi, 123-128. https://doi.org/10.1007/BF00041886

26) Roy, S.K., Hossain, M.Z. and Islam, M.S. (1994). Mass propagation of Rauvolfia by in vitro shoot tip culture. Plant Tissue Culture, 4(2), 69-75.

27) Salma, U., Islam, S., and Paul, B.C. (2008). Mass Propagation of Rauwolfia serpentina L. Benth. Pakistan Journal of Biological Sciences, 11(9), 1273-1277. https://doi:10.3923/pjbs.2008.1273.1277
28) Sayeed, S., Soleh, A. and Abdur, R.S.M. (2015). In vitro plant regeneration of potato (Solanum tuberosum L.) at the rate of different hormonal concentration. Asian Journal of Medical and Biological Research, 1(2), 297-303. https://doi.org/10.3329/ajmbr.v1i2.25625

29) Shahen MZ, Uddin ME and Alam MS. (2019). Effect of antibiotic susceptibility and inhibitory activity for the control of growth and survival of microorganisms of extracts of C. officinalis, Eur. J. Med. Health Sci. 1(1), 1-9. https://doi.org/10.34104/ejmhs.0190109

30) Steephen, M., Nagarajans. and Ganesh, D. (2010). Phloroglucinol and silver nitrate enhances axillary shoot proliferation in nodal explants of Vitex negundo L. An aromatic medicinal plant. Iranian J. of Biotechnology, 8(2), 82-89. http://www.ijbiotech.com/article 7108.html

31) Suvalaxmi, P., Rout, G.R., Das, A.K. and Dash, D.K. (2017). Callus Induction and Indirect Regeneration of Strawberry (Fragaria×Ananassa) Duch. CV. Chandler, 6(11), 1311-1318. https://doi.org/10.20546/ijcmas.2017.611.157

32) Vimla, M. and Satish, K. (2017). Micropropagation via shoot tip and nodal segment in ethnomedicinal plant Wood fordiafruticosa (L.) Kurz. IOSR Journal of Biotechnology and Biochemistry, 3(4), 44-48.

https://doi:10.9790/264X-03044448

33) Waseem, K., Sohail, K.M., and Ghazanfarullah, K. (2011). Effi-cient in vitro regeneration of chrysanthemum (Chrysanthemum morifolium L.) plantlets from nodal segments. African Journal of Biotechnology, 10(8), 1477-1484. https://doi:10.5897/AJB09.1820

34) Wenle, W., Jinfan, X., Huiyong, F., Zhijun, L. and Minhui, L. (2020). Advances and challenges in medicinal plant breeding. Plant Science, 298. https://doi.org/10.1016/j.plantsci.2020.110573

35) Yesmin, S., Das, K.C., Hasan, M.M. and Islam, M.S. (2014). Efficient In Vitro Regeneration of Chrysanthemum (Chrysanthemum morifolium Ramat.) Through Nodal Explant Culture. Nuclear Science and Application, 23, 1-2. https://doi:10.13140/RG.2.2.15980.67208

36) Yogendra, S., Pankaj, M. and Pushpendra, K. (2020). Morphology, Phytochemistry and Phar- 
macological Activity of Vitex negundo:An Over view. J. of Drug Delivery \& Therapeutics, 10(3s), 280-285.

https://doi.org/10.22270/jddt.v10i3-s.4173
37) Zhi-Qiang, C., Anders, F., Mats, B. and Harry, X.W. (2020). Advantage of clonal deployment in Norway spruce (Piceaabies (L.) H. Karst). Annals of Forest Science, 77(14), 1-15. https://doi.org/10.1007/s13595-020-0920-1

\section{SUPPLEMENTARY FILES}

S-1: Effect of $\mathrm{HgCl}_{2}(0.1 \%)$ on surface sterilization of explants (nodal segment and shoot tip) of V. negundo.

\begin{tabular}{|c|c|c|c|c|c|}
\hline $\begin{array}{c}\text { Treatment } \\
\text { period (min) }\end{array}$ & Total no. of & \multicolumn{2}{|c|}{ Rate of contamination (\%) } & Degree of tissue & Explants survived \\
\cline { 3 - 4 } & culture & After 5 days & After 15 days & & $(\%)$ \\
\hline 4 & $15-20$ & 40 & 42 & - & 35 \\
\hline 5 & $15-20$ & NC & 28 & + & 60 \\
\hline 6 & $15-20$ & NC & 10 & + & 75 \\
\hline 7 & $15-20$ & NC & NC & + & 89 \\
\hline 8 & $15-20$ & NC & NC & + & 95 \\
\hline 9 & $15-20$ & NC & NC & ++ & 30 \\
\hline 10 & $15-20$ & NC & NC & +++ & 25 \\
\hline
\end{tabular}

$* * * \mathrm{NC}=$ No contamination, $-=$ No tissue killing, $+=$ Partial tissue killing, $++=$ Moderate tissue killing, $+++=$ Massive tissue killing

S-2: Effects of diverse concentrations of BAP and Kinetin on MS medium for shoot propagation from shoot tip, and BAP+Kinetin treatment for shoot propagation and elongation.

\begin{tabular}{|c|c|c|c|c|c|}
\hline \multicolumn{2}{|c|}{ Treatment(mg/l) } & $\begin{array}{c}\text { Number of } \\
\text { explants inoculated }\end{array}$ & $\begin{array}{c}\text { \% of explants } \\
\text { producing shoot }\end{array}$ & $\begin{array}{c}\text { Average no. of the } \\
\text { shoot/explant }\end{array}$ & $\begin{array}{c}\text { The average length } \\
\text { of the shoot (cm) }\end{array}$ \\
\hline \multicolumn{2}{|c|}{ MS 0 (Control) } & 15 & 33.3 & $3.2 \pm 0.46$ & $1.7 \pm 0.19$ \\
\hline \multirow{3}{*}{ BAP } & 0.5 & 15 & 46.6 & $4.2 \pm 0.51$ & $2.58 \pm 0.15$ \\
\cline { 2 - 6 } & 1.0 & 15 & 80 & $5.5 \pm 0.61$ & $4.4 \pm 0.49$ \\
\cline { 2 - 6 } & 2.0 & 15 & 93.3 & $8.3 \pm 1.14$ & $4.5 \pm 0.48$ \\
\cline { 2 - 6 } & 3.0 & 15 & 53.3 & $7.2 \pm 0.65$ & $3.2 \pm 0.42$ \\
\hline \multirow{3}{*}{ Kinetin } & 0.5 & 15 & 33.3 & $3.2 \pm 0.29$ & $1.7 \pm 0.19$ \\
\cline { 2 - 6 } & 1.0 & 15 & 46.6 & $3.3 \pm 0.41$ & $1.7 \pm 0.19$ \\
\cline { 2 - 6 } & 2.0 & 15 & 73.3 & $5.8 \pm 0.42$ & $3.2 \pm 0.31$ \\
\cline { 2 - 6 } & 3.0 & 15 & 66.6 & $5.5 \pm 0.61$ & $2.5 \pm 0.15$ \\
\hline \multirow{3}{*}{ BAP+Kinetin } & $0.5+1.0$ & 15 & 80 & $5.3 \pm 1.63$ & $2.2 \pm 0.42$ \\
\cline { 2 - 6 } & $1.0+0.5$ & 15 & 53.3 & $3.67 \pm 0.32$ & $2.2 \pm 0.54$ \\
\cline { 2 - 6 } & $1.0+1.5$ & 15 & 73.3 & $4.2 \pm 0.51$ & \\
\hline
\end{tabular}

S-3: Various concentrations of BAP and Kinetin effectin MS medium by the combination with NAA and IAA for shoot regeneration from shoot tip.

\begin{tabular}{|c|c|c|c|c|c|}
\hline \multicolumn{2}{|c|}{ Treatment(mg/l) } & $\begin{array}{c}\text { Number of explants } \\
\text { inoculated }\end{array}$ & $\begin{array}{c}\text { \% of explants } \\
\text { producing the shoot }\end{array}$ & $\begin{array}{c}\text { Average no. of the } \\
\text { shoot/explant }\end{array}$ & $\begin{array}{c}\text { The average length of } \\
\text { the shoot (cm) }\end{array}$ \\
\hline \multirow{4}{*}{ BAP+NAA } & $1.0+0.1$ & 15 & 66.6 & $7.2 \pm 0.58$ & $2.23 \pm 0.57$ \\
\cline { 2 - 6 } & $1.0+0.5$ & 15 & 46.6 & $7.2 \pm 0.65$ & $2.78 \pm 0.19$ \\
\cline { 2 - 6 } & $2.0+0.1$ & 15 & 60 & $6.2 \pm 0.50$ & $3.2 \pm 0.46$ \\
\cline { 2 - 6 } & $3.0+0.1$ & 15 & 93.3 & $7.6 \pm 0.79$ & $3.9 \pm 0.32$ \\
\hline \multirow{4}{*}{ BAP+IAA } & $1+0.1$ & 15 & 60 & $5.4 \pm 0.52$ & $2.29 \pm 0.38$ \\
\cline { 2 - 6 } & $1.0+0.5$ & 15 & 66.6 & $5.1 \pm 0.65$ & $3.67 \pm 0.32$ \\
\cline { 2 - 6 } & $2+0.1$ & 15 & 86.6 & $6.0 \pm 0.61$ & $4.2 \pm 0.51$ \\
\cline { 2 - 6 } & $3.0+0.1$ & 15 & 80 & $5.1 \pm 0.65$ & $3.6 \pm 0.38$ \\
\hline \multirow{2}{*}{ Kinetin+NAA } & $1.0+0.5$ & 15 & 66.6 & $3.5 \pm 0.35$ & $1.62 \pm 0.27$ \\
\cline { 2 - 6 } & $2.0+0.1$ & 15 & 53.3 & $4.9 \pm 0.28$ & $1.50 \pm 0.49$ \\
\hline
\end{tabular}

UniversePG I www.universepg.com 


\begin{tabular}{|c|c|c|c|c|c|}
\hline & $3.0+0.1$ & 15 & 87 & $5.8 \pm 0.66$ & $1.94 \pm 0.46$ \\
\cline { 2 - 6 } & $5.0+0.1$ & 15 & 80 & $3.67 \pm 0.32$ & $1.12 \pm 0.17$ \\
\hline \multirow{4}{*}{ Kinetin+IAA } & $1+0.5$ & 15 & 53.3 & $3.6 \pm 0.44$ & $1.56 \pm 0.18$ \\
\cline { 2 - 6 } & $2+0.1$ & 15 & 60 & $4.9 \pm 0.38$ & $1.30 \pm 0.25$ \\
\cline { 2 - 6 } & $3.0+0.1$ & 15 & 86.6 & $5.5 \pm 0.41$ & $1.8 \pm 0.41$ \\
\cline { 2 - 6 } & $5.0+0.1$ & 15 & 80 & $5.1 \pm 0.65$ & $0.71 \pm 0.14$ \\
\hline
\end{tabular}

S-4: Effects of different concentrations of BAP and Kinetin on MS medium for shoot multiplication from the nodal segment, and BAP+Kinetin treatment for shoot proliferation and elongation.

\begin{tabular}{|c|c|c|c|c|c|}
\hline \multicolumn{2}{|c|}{ Treatment(mg/l) } & $\begin{array}{c}\text { Number of explants } \\
\text { inoculated }\end{array}$ & $\begin{array}{c}\text { \% of explants } \\
\text { producing the shoot }\end{array}$ & $\begin{array}{c}\text { Average no. of the } \\
\text { shoot/explant }\end{array}$ & $\begin{array}{c}\text { The average length of } \\
\text { the shoot (cm) }\end{array}$ \\
\hline \multicolumn{2}{|c|}{ MS 0 (Control) } & 15 & 33.3 & $3.2 \pm 0.31$ & $1.8 \pm 0.41$ \\
\hline \multirow{3}{*}{ BAP } & 0.5 & 15 & 60 & $6.8 \pm 0.75$ & $2.7 \pm 0.51$ \\
\cline { 2 - 6 } & 1.0 & 15 & 86.6 & $6.76 \pm 0.79$ & $3.3 \pm 0.41$ \\
\cline { 2 - 6 } & 2.0 & 15 & 93.3 & $7.1 \pm 0.68$ & $4.2 \pm 0.51$ \\
\cline { 2 - 6 } & 3.0 & 15 & 80 & $5.1 \pm 0.65$ & $3.67 \pm 0.32$ \\
\hline \multirow{3}{*}{ Kinetin } & 0.5 & 15 & 33.3 & $5.4 \pm 0.50$ & $2.23 \pm 0.57$ \\
\cline { 2 - 6 } & 1.0 & 15 & 66.6 & $5.1 \pm 0.65$ & $2.4 \pm 0.32$ \\
\cline { 2 - 6 } & 2.0 & 15 & 86.6 & $5.4 \pm 0.52$ & $2.7 \pm 0.17$ \\
\cline { 2 - 6 } & 3.0 & 15 & 53.3 & $4.5 \pm 0.48$ & $3.2 \pm 0.46$ \\
\hline \multirow{3}{*}{ BAP+Kinetin } & $0.5+1.0$ & 15 & 66.6 & $5.4 \pm 0.61$ & $3.9 \pm 0.65$ \\
\cline { 2 - 6 } & $1.0+0.5$ & 15 & 60 & $4.9 \pm 0.28$ & $2.68 \pm 0.34$ \\
\cline { 2 - 6 } & $1.0+1.5$ & 15 & & $3.6 \pm 0.38$ & $2.7 \pm 0.41$ \\
\hline
\end{tabular}

S-5: Effects of different concentrations of BAP and Kinetin in combination with NAA and IAA in the nodal segment of $V$. negundo L.

\begin{tabular}{|c|c|c|c|c|c|}
\hline \multicolumn{2}{|c|}{ Treatment(mg/l) } & \multirow{2}{*}{\begin{tabular}{|c|}
$\begin{array}{c}\text { Number of explants } \\
\text { inoculated }\end{array}$ \\
15
\end{tabular}} & \multirow{2}{*}{$\begin{array}{c}\begin{array}{c}\% \text { of explants } \\
\text { producing the shoot }\end{array} \\
73.3\end{array}$} & \multirow{2}{*}{$\begin{array}{c}\begin{array}{c}\text { Average no. of the } \\
\text { shoot/explant }\end{array} \\
7.2 \pm 0.41\end{array}$} & \multirow{2}{*}{$\begin{array}{c}\text { The average length of } \\
\text { the } \operatorname{shoot}(\mathbf{c m})\end{array}$} \\
\hline \multirow{4}{*}{$\mathrm{BAP}+\mathrm{NAA}$} & $1.0+0.1$ & & & & \\
\hline & $1.0+0.5$ & 15 & 86.6 & $8.1 \pm 0.71$ & $3.7 \pm 0.52$ \\
\hline & $2.0+0.1$ & 15 & 46.6 & $6.2 \pm 0.50$ & $2.23 \pm 0.51$ \\
\hline & $3.0+0.1$ & 15 & 93.3 & $8.5 \pm 0.52$ & $3.6 \pm 0.38$ \\
\hline \multirow{4}{*}{$\mathrm{BAP}+\mathrm{IAA}$} & $1+0.1$ & 15 & 80 & $6.2 \pm 0.61$ & $3.2 \pm 0.46$ \\
\hline & $1.0+0.5$ & 15 & 73.3 & $6.3 \pm 0.71$ & $4.1 \pm 0.49$ \\
\hline & $2+0.1$ & 15 & 86.6 & $6.8 \pm 0.18$ & $4.37 \pm 0.45$ \\
\hline & $3.0+0.1$ & 15 & 46.6 & $6.5 \pm 0.73$ & $2.37 \pm 0.45$ \\
\hline \multirow{4}{*}{ Kinetin+NAA } & $1.0+0.5$ & 15 & 86.6 & $7.3 \pm 0.41$ & $3.3 \pm 0.42$ \\
\hline & $2.0+0.1$ & 15 & 46.6 & $5.5 \pm 0.61$ & $0.42 \pm 0.22$ \\
\hline & $3.0+0.1$ & 15 & 86.6 & $7.2 \pm 0.23$ & $4.3 \pm 0.23$ \\
\hline & $5.0+0.1$ & 15 & 66.6 & $4.1 \pm 0.44$ & $3.9 \pm 0.65$ \\
\hline \multirow{4}{*}{ Kinetin+IAA } & $1.0+0.5$ & 15 & 60 & $4.2 \pm 0.51$ & $2.5 \pm 0.35$ \\
\hline & $2.0+0.1$ & 15 & 80 & $6.2 \pm 0.50$ & $4.1 \pm 0.43$ \\
\hline & $3.0+0.1$ & 15 & 66.6 & $5.8 \pm 0.53$ & $3.9 \pm 0.65$ \\
\hline & $5.0+0.1$ & 15 & 53.3 & $5.9 \pm 0.88$ & $3.6 \pm 0.40$ \\
\hline
\end{tabular}

Citation: Iqbal S, Huda AKMN, Mamun ANM, Islam MR, Jamal MAHM, and Karim MR. (2021). Effects of phytohormone and regulators on shoot tip and nodal explants for in vitro shoot and root clonal propagation of Vitex negundo L. Am. J. Pure Appl. Sci., 3(4), 65-78. https://doi.org/10.34104/ajpab.021.065078 @) () 